\title{
The Flexner Investigation of the University of Iowa Medical School
}

\section{STOW PERSONS}

Although fundamental advances in medical science were made during the nineteenth century the everyday practice of medicine lagged far behind, due primarily to the poor quality of medical education. At the turn of the century the American Medical Association established a program for the evaluation of medical schools, rating each school in one of three categories: acceptable, in need of certain improvements, or in need of complete reorganization. But the standards were so generously applied that many weak schools were found to be acceptable. ${ }^{1}$ Reform elements in the medical profession, apparently despairing of improvements from within, turned in 1905 to the Carnegie Foundation for the Advancement of Teaching with a request for an independent investigation of medical schools. Henry S. Pritchett, president of the foundation, chose as his investigator a layman, Abraham Flexner, a Louisville schoolmaster who had taken a Ph.D. in classics at Johns Hopkins University and had recently published a critique of American colleges. Pritchett saw in Flexner an energetic man with incisive literary gifts who was not afraid to take on the power of established institutions. ${ }^{2}$

Flexner began his survey in December 1908 and within a few months visited 155 medical schools in the United States and Canada. Many of these were proprietary schools operated for profit. In the absence of adequate professional accreditation

1. As late as 1910, the four Iowa schools of which Abraham Flexner was so sharply critical were all placed in the highest category (Des Moines Register, 19 June 1910).

2. Abraham Flexner, The American College: A Criticism (New York, 1908); idem, I Remember: The Autobiography of Abraham Flexner (New York, 1940), 3-99, 110-111. 
standards the training afforded by these schools was often abysmally poor. In evaluating each school Flexner used five criteria: (1) entrance requirements; (2) the size and training of the faculty; (3) the size of the budget and budget allocations; (4) the quality of the preclinical faculty and laboratories; and (5) the relationship between the medical schools and the hospitals, particularly with respect to the appointment of the doctors engaged in clinical teaching. Preclinical instruction in the basic medical sciences of anatomy, physiology, biochemistry, pathology, and pharmacology underlay the work in clinical medicine in which the student learned how to diagnose and treat the sick. Preclinical faculty members were not necessarily doctors of medicine; clinical faculty always were. It was generally the practice at that time to recruit professors in the clinical fields from the ranks of practicing physicians who continued to devote much of their time, and to receive most of their income, from private practice. It was fortunate for the future of medical education that Flexner's personal associations were with the Johns Hopkins medical school, at that time together with Harvard a leading center for medical education and research. The Hopkins school served as his model. It was a happy accident also that his brother was Dr. Simon Flexner, a distinguished medical scientist with whom Abraham was often confused during the course of his travels. ${ }^{3}$

The reformer had a strong sense of the proper status of medicine as a science built upon the basic medical sciences. Wherever he went his first concern was with the competence of the faculty and the quality of the facilities for instruction and research in the preclinical fields. There is little doubt that the severity of his overall criticism of the University of Iowa medical program was mitigated by his satisfaction with the quality of the instruction being offered in the basic medical sciences.

The Flexner report, published in 1910 as Medical Education in the United States and Canada, proved to be a bombshell. ${ }^{4}$ One of his objectives was to drive the proprietary schools out of business, reducing the total number of schools to about thirty-five. The time was ripe, and upon publication of the report many of

3. Flexner, I Remember, 110-127.

4. Abraham Flexner, Medical Education in the United States and Canada: $A$ Report to the Carnegie Foundation for the Advancement of Teaching (Bulletin \#4, New York, 1910). 
these proprietary schools collapsed immediately, while others consolidated. Thus the fifteen medical schools in Chicago combined into three. ${ }^{5}$

Flexner visited the University of Iowa Medical College in April 1909. Prior to the visit he had requested various categories of data and had notified President George MacLean that he would spend eight hours in Iowa City, visiting the various departments of the college and inspecting student records. MacLean accompanied him on his tour of inspection, but none of the clinical faculty were present, although they had been notified of the visit. In spite of the apparently cursory nature of the inspection, MacLean was nervous. ${ }^{6}$ He knew that behind Flexner stood the Carnegie Foundation whose financial resources were important to his plans for the development of the university. He had already waged a vigorous and successful campaign against such influential academicians as Charles William Eliot of Harvard and Woodrow Wilson of Princeton when he persuaded Carnegie to include public universities in the foundation's pension fund for retired professors. He had also attempted, this time unsuccessfully, to obtain foundation support for a Carnegie School of Library Science at the university. A favorable report from Flexner would undoubtedly strengthen the university's claim to future benefactions.

George MacLean had come to Iowa a decade earlier with ambitious plans to elevate the university to its proper place among the leading state universities of the Midwest. He had found a modest institution consisting of professional "departments" clustered around an academic "department," none of which thought of itself in terms of advanced graduate education. MacLean was the first at Iowa to envision a modern university with professional colleges based upon and drawing their students from the liberal arts colleges of the state. ${ }^{7}$ In 1909 the College of Medicine, housed in a group of small buildings with a

5. Flexner, I Remember, 130-131.

6. Flexner to MacLean, 22 April 1909, George E. MacLean Presidential Papers, University of Iowa Archives, University Libraries, Iowa City, Box 19-5.

7. The University of Iowa was not particularly laggard in this respect. Harvard did not require a bachelor's degree for admission to its professional schools until 1909 (C. Chester Lane to MacLean, 17 March 1909, MacLean Papers, Box 20-6). 
ninety-bed hospital on the north side of Iowa Avenue, boasted a faculty of fifteen professors. The students -267 in that yearwere admitted after one year of work in a liberal arts college. The preclinical faculty held full-time appointments; the clinical members served part time while devoting much of their time and energies to private practice. ${ }^{8} \mathrm{~A}$ county-seat town of nine thousand population, Iowa City could not itself support so large a concentration of medical skills. The school had always drawn many of the clinical faculty from surrounding communities where they continued to maintain regular practice. Five of the faculty also served as the medical staff of Mercy Hospital, a private facility in Iowa City.

Flexner's preliminary report to the foundation, a copy of which MacLean received early in July, was highly critical of the Iowa medical program. To be sure, the instruction and equipment in the preclinical fields was "generally good and at some points excellent." Flexner had high praise for Dr. Henry J. Prentiss, whose work in anatomy was as good as could be found anywhere. The same was to some extent true also of the work of Dr. John T. McClintock in physiology, and that of Dr. Henry Albert in pathology and bacteriology. Unfortunately, the clinical situation was a different matter altogether. The dean, Dr. James R. Guthrie, professor of obstetrics and gynecology, lived in Dubuque and came to the college twice weekly. The professor of surgery, Dr. William Jepson, lived in Sioux City and traveled all night for his weekly visit to the hospital. Under these circumstances it was not surprising to Flexner that the clinical work lacked correlation and close integration with the preclinical fields. Flexner found at Iowa precisely the fault he professed to see in American medical practice in general: a failure on the part of medical practitioners to keep abreast of the work in the basic medical sciences.

The clinical instruction given in a hospital with less than ninety beds available for clinical purposes was, in Flexner's opinion, wholly inadequate. The disorganization was apparent when the visitor could find no one, neither physician nor nurse, who could describe the system of bedside teaching. There were no hospital records worthy of the name. No hospital reports

8. Flexner, Medical Education, 223-24; Mercy Hospital brochure, MacLean Papers, Box 19-7. 
were compiled. It was impossible to determine what ground the clinical teaching had actually covered. While the eye-and-ear clinic was large, the medical clinic was small, and there were no clinics at all in surgery, gynecology, or urology. The conclusion was inescapable to Flexner that the clinical teaching methods were disorganized and antiquated.

The clinical opportunities could not be fully realized, in the visitor's opinion, without a resident dean, resident clinical faculty, and a hospital superintendent familiar with modern medical teaching. The hospital director was the vice dean and professor of theory and practice of medicine, Dr. Walter Bierring. To him fell the responsibility for adequate case histories and record keeping. Apart from deficiencies in personnel a major handicap was a hospital inadequate for clinical teaching. The one hundred students in the third and fourth years had access to less than ninety beds, too few for general medicine and surgery alone without considering the other clinical fields. The fifty students in obstetrics had had access to forty-five cases during the previous year, whereas there should have been at least 250 cases. Infectious diseases were omitted entirely, and the postmortem work was far too limited. Even with a hospital of adequate size, whether or not a small community could furnish the necessary number of patients remained a serious question.

Apart from all of these deficiencies of personnel and facilities Flexner directed the regents' attention to the larger question of whether a modern medical center in Iowa City could be justified in view of the national need to reduce the total number of schools and of the great cost of making the necessary number of improvements. Would it be a wise use of limited financial resources to put into medical education funds which would be better used in fields that were not handicapped by local conditions? The regents might well consider the experience of adjoining states. Chicago and Minneapolis provided the large populations to justify major medical centers. Michigan already had a highly developed medical school at Ann Arbor, yet even there the competition from the larger centers was keenly felt. The University of Wisconsin, with opportunities at Madison superior to those of Iowa City, had nevertheless decided to limit its medical school to the two preclinical years. Missouri had recently come to the same decision. Flexner warned in conclusion that as soon as an 


\section{Flexner Investigation}

additional year of undergraduate work was required for admission to the Iowa school the better trained and more mature students would perceive the inadequate quality of their instruction, with the result that the competition from Chicago and Minneapolis would become ever more severe. ${ }^{9}$

$I_{N}$ CONSTERnATION MacLean sent copies of the report to the heads of the medical departments with a request for the strongest possible positive response to Flexner's criticisms. He told the department heads bluntly that "the University is being held back on account of the College of Medicine. ${ }^{10}$ But if he expected constructive proposals to strengthen the program he was disappointed. The professors in the preclinical fields, who had received generally favorable notice, tactfully observed that fault had not been found with them. The clinical professors were not prepared to acknowledge any shortcomings. Either Flexner's data were faulty or his complaints were without merit. Dr. William Jepson, writing from his residence in remote Sioux City, was openly contemptuous of "a certain Abraham Flexner" who was apparently "'drumming up trade,'(as the Jew would say) for Minneapolis and Chicago." Jepson saw no need to respond to the report in specific terms since he found the facts as stated to be so far from the truth. ${ }^{11}$

The complaints of the medical faculty were loud enough to be heard in the Carnegie offices in New York, and President Pritchett asked Flexner to take another look, accompanied this time by Dr. R. H. Whitehead, dean of the University of Virginia College of Medicine. Charlottesville was also a small community, and Whitehead could be expected to be familiar with the problems of operating a medical school under conditions similar to those in Iowa City. ${ }^{12}$

9. Abraham Flexner, "State University of Iowa. Medical Department," MacLean Papers, Box 19-6. Box 19-7.

10. MacLean to Dean James R. Guthrie, 7 July 1909, MacLean Papers,

11. H. J. Prentiss to MacLean, 12 July 1909; E. W. Rockwood to MacLean, 8 July 1909; W. E. Bierring to MacLean, 9 July 1909; William Jepson to MacLean, 19 July 1909; all in MacLean Papers, Box 19-6.

12. William R. Boyd, "A Brief History of the Development of the College of Medicine of the Iowa State University," Appendix B in Carl B. Cone, "His- 
In the interval between visits the university experienced a change in management. Its own Board of Regents was replaced by a new Board of Education which also had jurisdiction over the state college at Ames and the normal school at Cedar Falls. Like its predecessors the new board was composed of unsalaried citizens who gave to its business such time as they could spare from their own pursuits. The law provided the board with a full-time Finance Committee of three salaried employees whose usefulness to the board proved to be so great that the committee's functions quickly expanded beyond the financial matters originally assigned to it. The first president of the Finance Committee was William R. Boyd, a Cedar Rapids journalist and alumnus of the university. No individual ever served the university more effectively than did William R. Boyd. Formulating a response to Flexner was to be the first challenge to the new board, and there can be no doubt that Boyd played a crucial part in determining its policy.

When Flexner notified MacLean of his return visit the president begged Boyd to accompany the visitor on his rounds. After the inspection Boyd and Flexner returned to the verandah of the St. James Hotel on Clinton Street where they put their feet up on the railing and had a long talk. The details of the conversation are not recorded, but it is apparent that Boyd succeeded in persuading Flexner that the Board of Education took his criticisms with the utmost seriousness, and that it was determined to maintain a medical school of the first rank. Boyd kept up his contacts with Flexner during the latter's association with the Carnegie Foundation, and later, when Flexner was an officer of the Rockefeller Foundation. Many years afterwards, Flexner penned a striking tribute to Boyd as "the highest type of American citizen: absolutely correct, candid, and straightforward; absolutely without personal ambition; absolutely devoted to the welfare of his State and particularly to the upbuilding of the State University." 13

tory of the State University of Iowa: College of Medicine" (University of Iowa Libraries, 1941), 159. Cone, whose research was done prior to 1941, had corresponded with Bierring, Dean, Whiteis, Van Epps, and Teeters, all faculty members at the time of the investigation.

13. Flexner, I Remember, 127, 291-92; MacLean to Boyd, 28 October 1909, MacLean Papers, Box 18-3. 
In the report on his second visit, addressed to Board President James H. Trewin, Flexner noted that while some improvements had been made since his first visit, presumably in the matter of record keeping and plans for hospital enlargement, there was still no clear understanding of the changes necessary to bring the college up to modern standards. The principal problem was the inadequate clinical departments. The nonresidence of important senior faculty members was a partial explanation, but ultimately the clinical faculty were not in all respects up-todate medical men. The school's prime need was a resident dean who would be the chief clinician with full authority over the faculty, able to insist upon residence in Iowa City, and determined to eliminate inbreeding. But it is important to note that in contrast to his first impressions, Flexner was now persuaded that it was feasible to develop a strong medical faculty in a small town. He was impressed with the determination of the board to deal vigorously with the matter. ${ }^{14}$ This significant change undoubtedly reflected the influence of $W$. R. Boyd.

Dr. Whitehead was even more pointed in his criticisms. The facilities for clinical instruction, he noted, were entirely inadequate. The hospital was too small, and the number of patients too few for proper clinical instruction, with the exception of the eye-ear-nose-and-throat department. The internal medicine department was most deficient. The instruction in this department was too didactic and demonstrative, both outmoded and oldfashioned; the students were not being sufficiently involved with the patients. With the professors of gynecology and surgery not in residence it was inevitable that there should be inadequate clinical supervision of students. ${ }^{15}$

The most imperative need, in Dr. Whitehead's opinion, was a new dean of sufficient energy and ability to institute the necessary reforms. He should be thoroughly conversant with modern methods, possessed of the authority to clean house, and free to

14. Flexner to James H. Trewin, 8 November 1909 , MacLean Papers, Box 19-6.

15. Dr. Jepson had in fact been appointed professor of surgery in 1902 with the understanding that he would move his residence to the lowa City area, but he had subsequently repudiated the agreement on the ground that the university had failed to provide him with stipulated clinical assistance (Jepson to MacLean, 8 November 1909, MacLean Papers, Box 20-4). 
devote full time to the job. His most important task would be to reform the methods of clinical instruction. Without saying so directly, Whitehead clearly implied that the present clinical faculty would have to be replaced. The dean himself should be an internist of sufficient standing to attract difficult cases by referral, thus increasing the supply of clinical materials. ${ }^{16}$

In his published report Flexner's criticisms of the Iowa medical program were muted. He noted that the state had two to three times as many physicians as were needed for a stable population. There was no justification for training more doctors unless it were to improve the quality of medical care. None of the four existing schools-Drake and the Osteopathic College in Des Moines, and the two colleges in lowa City-were up to this challenge, although the regular medical college at the university was clearly the most promising candidate. Apart from the antiquated training in the clinical fields the chief deficiency was the hospital, which provided inadequate facilities for clinical training and insufficient numbers of patients for the clinics. On the positive side, the report noted the capable preclinical faculty and laboratory facilities. Plans to enlarge the hospital were noted with approval. In conclusion, Flexner believed that a strong resident faculty and the wise use of state patients would permit the University of Iowa medical school to duplicate what Michigan had achieved at Ann Arbor. ${ }^{17}$

Flexner's opinion of the "other" medical college in Iowa City was not so favorable. There is no evidence that Flexner visited the university's Homeopathic Medical College, although he received data on the program and included it in his published report. Instruction in homeopathic medicine had been introduced in 1876 by legislative fiat, and was maintained by the continuing political pressure of state and county homeopathic medical societies. Flexner had no use for homeopathic medicine, which was clearly waning in public patronage by the early twentieth century. Fifteen homeopathic medical colleges remained in the United States, none of them requiring more than a high school education for admission. With an enrollment of only forty-two students; a budget of $\$ 5,453$; income from fees a mere $\$ 1,864$;

16. Whitehead to Flexner, 7 November 1909, MacLean Papers, Box 19-6.

17. Flexner, Medical Education, 223-25. 
and a hospital budget of $\$ 7,847$; the Iowa Homeopathic Medical College was only surviving due to the reluctance of the legislature to offend a vocal constituency. Flexner pointed out that the homeopathic college was only half of a school-the clinical half. Instruction in the preclinical subjects was provided by the regular medical faculty, none of whom were in sympathy with homeopathy. Work in the preclinical fields was premised on one or two years of college science, which must have put the homeopathic students at a further disadvantage. Their handicap was in fact so great that the homeopathic faculty proposed that separate instruction be provided for first-year homeopathic students in physiology and histology. Flexner found that in general, although homeopaths agreed that medicine was a science, they had contributed nothing to its development during the century of the sect's existence. Their fundamental assumption was sacred, and no science could flourish where dogmas were exempt from critical inspection. The "sacred" dogma of homeopathy was the "Law of Similars," the belief that a substance was of therapeutic value for a given disease if it produced in a healthy person the symptoms exhibited by a sick person. Homeopathy was little more than a theory of therapeutics, and its identification of the disease with its symptoms was an idea long since abandoned by scientific medicine. In his published report Flexner recommended that the two university medical colleges be combined, with optional courses in homeopathic materia medica and therapeutics for those students desiring a homeopathic diploma. Given the long-standing professional and social barriers that separated the two medical traditions he must have known that any such union would be impracticable. ${ }^{18}$

Following the receipt of Flexner's and Whitehead's reports it quickly became apparent that the medical faculty acknowledged neither shortcomings nor need for reform. The only action by the faculty was the unanimous adoption of a resolution introduced by Dr. Jepson affirming full confidence in Dean Guthrie and dismissing as unjust the charge that he was in any way responsible for the condition of the college. ${ }^{19}$ Since the fac-

18. Ibid., 159, 224.

19. State University of Iowa, Medical Faculty Records, 7 December 1909 , University Archives, 36-37; MacLean to Trewin, 9 December 1909, MacLean Papers, Box 22-4. 
ulty could hardly have intended to imply that the dean had no responsibilities, this curious resolution was presumably intended simply to affirm support of his administration. If there was to be a positive response it would have to come from the initiative of President MacLean and the Board of Education.

THE BOARD'S RESPONSE was soon forthcoming. Its initial impulse was to adopt the suggestion in Flexner's first report and abandon the clinical part of the medical program. But Boyd was determined to preserve and develop the college in Iowa City, and he persuaded the board to put the matter to the legislature. Meanwhile he proceeded as though the legislature would support his position by shifting current funds from other parts of the university budget to the medical college. He addressed a letter to medical college alumni assuring them that contrary to rumors of abandonment, the board intended to ask the next legislature to do more for the college than it had ever done before. ${ }^{20}$ He then met with the university faculty, many of whom, he noted, were his former teachers, and asked them to forgo budgeted salary increases in order to save the medical college. He must have been a singularly persuasive man, for the faculty consented to freeze their own salaries, while the legislature subsequently agreed to a much larger medical appropriation. ${ }^{21}$

In its first biennial report, issued in 1910, the board formally announced its intention to strengthen the medical college and secure its position among the leading institutions of the region. Eminent resident professors would be appointed to the faculty, the hospital would be enlarged, and more clinical material would be provided by arranging for the treatment of indigent patients at public expense. The board's announced object was to improve the quality of medical education, not to increase the number of practicing physicians. ${ }^{22}$

One of Boyd's concerns was to forestall a movement to transfer the medical college to Des Moines. Flexner had also visited the Drake Medical School where he found an institution without any full-time faculty or hospital of its own, dependent

20. W. R. Boyd, "Letter to Alumni," 11 July 1910, MacLean Papers, Box 23-3; Des Moines Register, 17 July 1910.

21. Boyd, "Brief History," 6-7.

22. Iowa State Board of Education, First Biennial Report, 1910, 10-11. 
on student fees for virtually its entire budget of $\$ 12,417$. Doubtless anticipating a devastating report, the faculty voted in April 1910 to abandon the school. The Des Moines Register thereupon inaugurated what it hoped would be a crusade to transfer the university medical college to the capital city. The paper bitterly criticized the Carnegie Foundation for allegedly using the threat of withholding pension funds from institutions that refused to bow to its dictates in educational matters. The prospect of fragmenting the university lent urgency to the board's determination to strengthen the program in Iowa City. ${ }^{23}$

If any one individual bore the brunt of the FlexnerWhitehead criticism it was the professor of the theory and practice of medicine and clinical medicine, Dr. Walter L. Bierring, who was also vice dean of the college and hospital director. In the absence of Dean Guthrie, the daily management of the college was his responsibility. The complaints about antiquated clinical teaching and about inadequate hospital record keeping pointed directly at him, as did the recommendation that the key to improvement would be the appointment of a competent and respected internist. The board wanted him to give up his large private practice and devote full time to the college. ${ }^{24}$ This he was unwilling to do, and bowing to the pressure he resigned from the medical faculty to accept appointment at the Drake Medical School, which collapsed three years later, in 1913.

Dr. Bierring's resignation presented the first opportunity to make the strong appointments that the board had promised. A national-indeed international-search was immediately inaugurated to find the most promising available teacher and research scientist in the field of internal medicine. Although Dean

23. Flexner, Medical Education, 222; Des Moines Register, 6,9,11 April 1910.

24. Boyd, "Brief History," 8; Board of Education, "Faculty and Finance Committee Minutes," 3 June 1910, University Archives, 264; Trewin to MacLean, 4 June 1910, MacLean Papers, Box 27-2. A prolific publisher of medical papers, Dr. Bierring went on to a long and successful career in organized medicine, culminating in the presidency of the American Medical Association. Nearly half a century after he left the university, when Dr. Bierring wrote his History of the Department of Internal Medicine, State University of lowa, 18701958 (lowa City, 1958), he referred in passing to the Carnegie survey but without specific mention of Flexner's Iowa investigation (45-48). He did, however, describe his methods of clinical teaching at that time, and he referred to his hospital reports, copies of which have not been found. Apparently the Flexner criticism still rankled. 
Guthrie participated in the search the initiative was taken by President MacLean and W. R. Boyd. The most eminent teachers in the field were consulted, including Sir William Osler, of Oxford University; Dr. William $\mathrm{H}$. Welch, of Johns Hopkins; and Dr. Frank Billings, of the Rush Medical College. The applications of Iowa alumni were politely but firmly set aside. Choice finally settled upon a former student of Osler's, Dr. Joseph H. Pratt, of the Harvard medical faculty. When Pratt declined to be a candidate MacLean turned to another of Osler's students, Dr. Campbell P. Howard, of McGill University. Boyd hastened to Montreal to assure Dr. Howard that the board would provide the additional staff member and research funds and facilities he had stipulated as conditions for acceptance. Howard's appointment represented a new concept at lowa, namely, the emergence in the clinical fields of a teacher-research scientist, one who devoted most of his time and energy to those activities, carried on in a hospital and clinical setting, but without a major commitment of time and energy to the care of private patients. When Dr. Jepson complained that his $\$ 1,100$ salary was less than Dr. Howard's, the university's president pointed out that Dr. Howard's salary of $\$ 4,000$ was a full-time salary, whereas the surgeon's made allowance for his part-time service. ${ }^{25}$

President MacLean's successor, John G. Bowman, came to the university in 1911 from the position of secretary to the Carnegie Foundation. As a friend and associate of Flexner's he was even more determined than his predecessor to carry out the proposed reforms. The physiologist Dr. John T. McClintock re-

25. R. Palmer Howard, The Chief: Dr. William Osler (Canton, Mass., 1983), 54-56; MacLean to Dr. Frank Billings, 6 July 1910, MacLean Papers, Box 23-3; Cone, "College of Medicine," 172; MacLean to Boyd, 20 July 1910, MacLean Papers, Box 23-3; MacLean to Faculty Committee, Board of Education, 19 July 1910, MacLean Papers, Box 24-3; John G. Bowman to Jepson, 22 May 1913, William Jepson file, Medical College Papers, University Archives.

It is possible that the paramount position of the law faculty among the professional colleges of the university throughout those years may be accounted for, at least in part, by the fact that in the legal profession the distinction between teaching and practice as full-time occupations was commonly recognized. When senior appointments in the Iowa law faculty were under consideration a large pool of experienced law teacher-scholars existed among whom attractive choices could be made. Such a distinction was only beginning to appear in American medical education. 
placed Bierring as junior dean, and Dr. Lee W. Dean succeeded Bierring as hospital director. Dr. Dean, the professor of ophthalmology and otology, maintained a large and efficiently organized eye-ear-nose-and-throat clinic at Mercy Hospital. His managerial skills appealed to Bowman, who appointed him dean of the college in 1914. (Dr. Guthrie, who had refused to move to lowa City, became Dean Emeritus.) Under Dr. Dean's aggressive management the college was to undergo rapid expansion. Protracted negotiations to bring Dr. Jepson into residence finally collapsed, and he resigned in 1913, to be succeeded as head of surgery by Dr. Charles J. Rowan, of the Rush Medical College. ${ }^{26}$

The appointment of outsiders brought to the fore the problem of inbreeding. One aspect of the professionalization of knowledge during the nineteenth century was a growing conviction of the undesirable consequences of inbreeding. Professional training should involve an awareness of the latest advances in the field wherever made, a principle to which exclusive localisms seemed to present a standing challenge. In support of his criticism of inbreeding Flexner noted that 87 percent of the medical students were lowa residents, and that of the fifteen faculty members in 1909 eleven held their medical degrees from the university. No doubt it appeared to the investigator that here were the makings of a self-perpetuating provincialism that could fall behind the general medical advance. One of the undesirable aspects of inbreeding was the jealous possessiveness that resented what was felt to be outsider incursions into a cherished monopoly. The state medical community which included many alumni of the college was inclined to look upon the college as its own possession. It expected to supply the faculty as a matter of right. There was apparently no opposition to the appointment of Dr. Howard, but the appointment of Dr. Rowan generated widespread opposition. Sensitive to local sentiment Board President Trewin reprimanded Bowman sharply for having appointed Rowan without consulting Dean Guthrie, and he insisted that junior appointments in surgery be made without awaiting the

26. MacLean to L. W. Dean, 19 July 1910, MacLean Papers, Box 24-1; Bowman to J. L. King, 14 November 1912, William Guthrie file, Medical College Papers; Bowman-Jepson correspondence, Jepson file, Medical College Papers. 
appointment of a department head..$^{27}$ Bowman's aggressive approach to medical reforms was one of the factors leading to his forced resignation in 1914.

Meanwhile, the implementation of Flexner's recommendations concerning the College of Homeopathic Medicine proved to be unexpectedly difficult. As a first step the board equalized the entrance requirements of the two colleges: two years of undergraduate work, including a year each of physics, chemistry, biology, and a foreign language would now be required. The homeopaths were understandably unhappy with the new requirements because enrollments would be curtailed, and homeopathic students, now on an academic par with regular students, would be exposed to enticements to transfer to the regular medical college. ${ }^{28}$ Although President MacLean considered homeopathy to be a delusion he felt it his duty to support what the legislature had mandated, and the homeopathic faculty believed that he treated them fairly. President Bowman was also unsympathetic, but armed with Flexner's opinion and the board's keen desire for economy and the elimination of duplicating programs he moved forcefully against homeopathy. On his recommendation the board determined to consolidate all work in surgery, obstetrics and gynecology, and eye-ear-noseand-throat in the regular college, leaving the homeopathic college only its distinctive chairs in materia medica and therapeutics. The homeopaths objected strenuously, maintaining that homeopathic therapy permeated all branches of medical practice and that the medical specialities could not be successfully separated from it. The board assured them that its intention was merely to achieve economies of operation, and that patients desiring it would be provided with homeopathic care before and after treatment in the regular departments. Bowman agreed reluctantly to this concession, and homeopathic dean George Royal later complained that the pledge was not kept. Despairing of support within the university the homeopaths turned to the legislature, where their well-organized state and regional medi-

27. Bowman to Trewin, 20 October 1913; Trewin to Bowman, 15 October 1913; both in John G. Bowman Presidential Papers, University Archives, Box 5-1.

28. Board of Education Minutes, 10 April 1910, University Archives, 197; George Royal to Trewin, 21 January 1910, MacLean Papers, Box 26-4. 
cal societies could bring pressure. The Thirty-fifth General Assembly in 1913 obligingly established in the homeopathic college chairs in surgery, eye-ear-nose-and-throat, and obstetrics and gynecology, thus prolonging the life of a dying institution. ${ }^{29}$

Neither Flexner nor Whitehead had referred to the practice of fee-splitting, an abuse that was firmly established in Iowa medical practice at that time. The journal of the Iowa State Medical Society reported that there was abundant evidence that "some of the most prominent members of the clinical faculty" engaged in the practice of remitting to outside physicians a portion of the fees charged to patients referred to them. Both MacLean and Bowman publicly condemned fee-splitting as unprofessional and unethical. Upon Bowman's insistence the medical faculty unanimously repudiated the practice, and the board subsequently confirmed the action, although only by majority vote. The Des Moines Register reported that Dr. William R. Whiteis, professor of obstetrics, used his influence with certain board members in an attempt to obtain a reversal of the decision. After considerable vacillation the board finally decided to reaffirm its condemnation of fee-splitting. ${ }^{30}$

THE YEAR 1915 marked the full response of the university to the Flexner investigation. The vexed problem of private practice versus public service was by no means settled in that year, but a principle was adopted that would eventually furnish the framework for achieving a satisfactory relationship. The issue was precipitated by a curiously archaic complaint. Certain physicians complained to the Board of Education that the university hospital, a public institution, was being monopolized by faculty physicians for the treatment of their private patients to their own profit. Should not a public hospital be available to any physician who might wish to use it? The complaint reminds us of the early days of railroading, when certain entrepreneurs ar-

29. Iowa State Board of Education, Second Annual Report, 29-30; Board of Education, Finance Committee Minutes, 14 January 1910, University Archives, 133; numerous letters in the Bowman Papers, Box 1-126, 4-206, and 4-208; "Medical Faculty Records," 12 March 1912, 58.

30. Journal of the lowa State Medical Society 1 (1911), 127, 276-78; "Medical Faculty Records," 54; Bowman to Flexner, 18 September 1911, Bowman Papers, Box 2-151; Des Moines Register, 22 March 1914. 
gued that anyone should have the right to operate a train on tracks laid by right of eminent domain. Nevertheless, President Bowman was obliged to take the matter seriously. He consulted law dean Henry W. Dunn, who submitted a lengthy explanation of why such a practice would be both unwise and impracticable. ${ }^{31}$

But the deeper question as to the proper allocation of a faculty member's time and energies was thus brought to the surface. On June 7, 1915, the medical faculty unanimously adopted a regulation affirming that only those physicians willing to make private practice "wholly secondary" to teaching were to be appointed to faculty positions. "An extensive, time-consuming private practice is not permissible." Each clinical teacher was to spend an average of at least three hours daily in the hospital during the college year. Clinical patients were to have precedence over private patients wherever hospital space was limited. Private patients were to be available for clinical teaching wherever the head of department considered it appropriate. ${ }^{32}$ Controversy and ill-feeling arising out of private practice was by no means settled by these regulations, but they at least asserted principles by which private practice would eventually be successfully integrated into a teaching and research institution.

Also in 1915 Dean Lee W. Dean called the attention of the faculty to the fact that although the college had acquired an excellent reputation as a teaching institution it was not known for its contributions to medical research. The faculty thereupon voted unanimously to inform the Board of Education that it would thereafter be the policy of the college to expect that every member of the instructional staff would engage actively in research. ${ }^{33}$

Finally, in his original report Flexner had expressed grave doubts about the ability of the small lowa City community to provide the necessary volume of clinical material to support an adequate teaching hospital. Boyd and others had subsequently persuaded him that the state could be prevailed upon to furnish patients at public expense. Such assurance could more readily

31. Dunn to Bowman, received 3 March 1914, Bowman Papers, Box 2-161; Bowman to H. M. Eicher, 7 March 1914, Bowman Papers, Box 5-1.

32. "Medical Faculty Records," 7 June 1915, 97.

33. Ibid., 13 December 1915, 108. 
be given than actually realized. It took five years of hard work to persuade the legislature, in 1915, to provide medical care for the children of indigent parents, as well as care for inmates of correctional institutions under the Board of Control. A children's hospital was authorized two years later. And in 1919, provision was made for the treatment of all indigent adults. The problem of clinical material was now solved. Thus within a decade of his first visit Flexner had the undoubted satisfaction of seeing a feeble institution of purely local usefulness begin the process of transformation that would eventually establish its position as a major medical center. ${ }^{34}$

34. Boyd, "Brief History," 9-10; Laws of Iowa, 36th General Assembly, Chapter 24, 47-51; 38th General Assembly, Chapter 78, 86-88. 
Copyright of Annals of Iowa is the property of State of Iowa, by \& through the State Historical Society of Iowa and its content may not be copied or emailed to multiple sites or posted to a listserv without the copyright holder's express written permission. However, users may print, download, or email articles for individual use. 